\title{
GEOLOGICAL MÁGAZINE
}

Edited by

O. M. B. BULMAN, S. R. NOGKOLDS, and W. B. HARLAND

assisted by

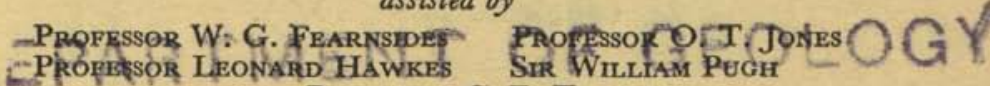

Professor C. E. Tilley

BIRKBEOK COLLEGE

UNIVERSTIYOF LONDON

GONTENTS

PAGE

Ruxton, B. P. Weathering and Subsurface Erosion in Granite at The Piedmont Angle, Balos, Sudan

ReYNolds, Doris L. Granite: Some Tectonic, Petrological, and Physico-Chemical Aspects .

Broadhurst, F. M., and R. A. HowIE. On the Occurrence of Ankerite in a Band of Non-marine Lamellibranchs from the Lancashire Coal Measures.

MuIr, I. D., and C. E. Trlley. The Compositions of Coexisting Pyroxenes in Metamorphic Assemblages

LAFUSte, JeAn G. Note on the Structure and Microstructure of Thecia swinderniana (Goldf.) . $\quad . \quad . \quad . \quad . \quad . \quad 409$

Hudson, R. G. S. The Upper Jurassic Faunas of Southern Israel . 415

\section{CORRESPONDENCE}

pp. $426-440$

STEPHEN AUSTIN \& SONS, LTD. CAXTON HILL, WARE ROAD, HERTFORD, HERTS 
THE

\title{
GEOLOGIGAL MAGAZINE
}

\author{
VOL. XCV OF WHOLE SERIES
}

JANUARY-DECEMBER, 1958 


\section{GEOLOGICAL MAGAZINE}

with which is incorporated

\section{THE GEOLOGIST}

Founded in 1864 by the Late Dr. Henry WoOdward, F.R.S.

Edited by

O. M. B. BULMAN, Sc.D, A.R.G.Sc., F.R.S.,

S. R. NOGKOLDS, Ph.D.,

and

W. B. HARLAND, M.A.

assisted by

Professor W. G. Fearnsides, M.A., F.R.S.

Professor Leonard Hawkes, D.SC., F.R.S.

Professor O. T. Jones, M.A., D.Sc., F.R.S.

Professor Sir William PUgh, O.B.E., D.Sc., F.R.S.

Professor C. E. Tilley, Ph.D., F.R.S.

Vol. XCV of Whole Series

JANUARY-DECEMBER, 1958

STEPHEN AUSTIN \& SONS, LTD.

CAXTON HILL, WARE ROAD, HERTFORD, HERTS 
Stephen Austine sons tro

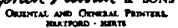




\section{CONTENTS OF VOLUME XCV, 1958}

No. 1

JANUARY-FEBRUARY

PAGE

R. Neves. Upper Carboniferous Plant Spore Assemblages from the Gastrioceras subcrenatum Horizon, North Staffordshire

W. E. Nevill. A Note on the Occurrence of Coal Measures in Eastern County Limerick, Ireland

G. H. Francis. The Amphibolite of Doir'a'Chatha (Durcha), Sutherland

N. F. Hugres. Palaeontological Evidence for the Age of the English Wealden

N. J. Snelling. Further Data on the Petrology of the Saxa Vord Schists of Unst, Shetland Isles

D. H. Mackenzie. The Structure of the Grantown Granite Complex, Morayshire

A. Hallam. A Cambro-Ordovician Fauna from the Hecla Hoek Succession of Ny Friesland, Spitsbergen . . . .

D. G. JoNes. A note on new Namurian Plant localities at the head of the Neath Valley, South Wales

Correspondence.-A Use for Acetic Acid in the Study of Fossil Sponges, 82 ; On some Turkish Sediments, 83 ; Recent Marine Deposits near Basrah, 84 ; Namurian Stage Names, 85.

Reviews.--Glacial and Pleistocene Geology, 86 ; Mio-Pliocene Floras from West-Central Nevada, 87; Fossilium Catalogus II : Plantae, 87; A Treatise on Limnology, 87; Lehrbuch der Tektonischen Geologie, 88.

W. B. HARLAND and M. B. BAYLY. Tectonic Regimes . . .

R. TAVENER-SMith. The Development of the Mid-Zambezi Valley in Northern Rhodesia since Early Karroo Times . . . . 105

P. F. Hurchins. Devonian Limestone Pebbles in Central Devon . . 119

C. A. Cotron. Alternating Pleistocene Morphogenetic Systems . 125

A. A. DAY. The Pre-Tertiary Geology of the Western Approaches to the English Channel

S. Moorbath, S. R. TAylor, and B. G. J. Upton. Age of Zircon from the Kunait Syenite Complex, South-West Greenland . . .

C. L. Forbes, K. A. JoYsey, and R. G. West. On Post-Glacial Pelicans in Britain

R. W. Hey. High-level Gravels in and near the Lower Severn Valley .

CORRESPONDENCE.-On Some Turkish Rocks, 169; Antidunes and Flame Structures, 169; Load-cast Structures, 171; Igneous Rocks at Gorei, Shilemadu Range, British Somaliland, 172.

Review.-Mesures Gravimétriques et Magnétiques dans la Partie Centrale de l'A.O.F., 174.

Publications Received. -176. 
R. St. J. LAMbert. A Metamorphic Boundary in the Moine Schists of the Morar and Knoydart Districts of Inverness-shire . .

P. Stone and G. M. Brown. The Quihita-Cunene Layered Gabbroic Intrusion of South-west Angola

A. Williams. Oblique-Slip Faults and Rotated Stress Systems .

D. E. B. Bates and W. Schwarzacher. The Geology of the Land between Ekmanfjorden and Dicksonfjorden in Central Vestspitsbergen... . . . . .

A. J. SMITH and N. RAST. Sedimentary Dykes in the Dalradian of

I. G. Gass. Ultrabasic Pillow Lavas from Cyprus . . . .

I. McDougall and R. Green. The Use of Magnetic Measurements for the Study of the Structure of Talus Slopes. . .

CORRESPONDENCE. - The Carboniferous Upland Flora, 261.

Notice.-University of New England, Armidale, N.S.W., 262.

Publications Received.-262.

REVIEws.-Die Geotektonische Entwicklung des Apennin-Systems, 263 ; Studies on Fossil Vertebrates, 263; Phreatophytes, 264 ; Fossilium Catalogus II : Plantae, 264.

No. 4

JuLY-AugusT

M. S. RAO. Composite and Multiple Intrusions of Lamlash-Whiting Bay Region, Arran

B. E. LEAKE. Composition of Pelites from Connemara, Co. Galway, Ireland

A. N. Carter. Pelagic Foraminifera in the Tertiary of Victoria

C. B. Wilson. The Lower Middle Hecla Hoek Rocks of Ny Friesland

H. C. Squirrell. New Occurrences of Fish Remains in the Silurian of the Welsh Borderland

T. N. Clifford. A note on kyanite in the Moine Series of Southern Ross-shire, and a review of related rocks in the Northern Highlands of Scotland

R. Gradwell. Post-Tectonic Granite-Gabbro Complexes in Southeastern Queensland

CORRESPONDENCE.-The Evolutionary Plexus, 351 ; Development of Lineation in Complex Fold Systems, 351 .

No. 5

SEPIEMBER-OCTOBER

B. P. Ruxton. Weathering and Surface Erosion in Granite at the Piedmont Angle, Balos, Sudan

D. L. Reynolds. Granite: Some Tectonic, Petrological, and PhysicoChemical Aspects

F. M. BroAdHuRst and R. A. HowiE. On the Occurrence of Ankerite in a Band of Non-Marine Lamellibranchs from the Lancashire Coal Measures

I. D. Muir and C. E. Tilley. The Compositions of Coexisting Pyroxenes in Metamorphic Assemblages . . .

J. G. LAFuste. Note on the Structure and Microstructure of Thecia swinderniana (Goldf.) 
R. G. S. Hudson. The Upper Jurassic Faunas of Southern Israel

Correspondence.-The Evidence for Cosmic Upward Pull in Mountain and Land Uplift, 426 ; Ultrabasic Pillow Lavas from Cyprus, 436; Pelagic Foraminifera in the Tertiary of Victoria, 438; Development of Lineation in Complex Fold Systems, 439; Derived Ammonites in Basal Cretaceous Conglomerate, 440.

\section{No. 6}

\section{NOVEMBER-DecEMBER}

G. E. G. Westermann. The Significance of Septa and Sutures in Jurassic Ammonite Systematics

A. T. V. Rothstein. Pyroxenes from the Dawros Peridotite and some comments on their nature

D. S. Buist. The Bostonite of Rudh'a' Chromain, Carsaig, Mull

C. L. Forbes, W. B. Harland, and N. F. Hughes. Palaeontological Evidence for the Age of the Carboniferous and Permian Rocks of Central Vestspitsbergen

R. PotoniÉ. Views on Spore Nomenclature . . . .

J. L. KNiLl and D. C. KNILl. Some Discordant Field Structures from the Dalradian of Craignish, Argyll, and Rosguill, Co. Donegal

CORRESPONDENCE.-Picrite, 511; Dimensions of Asymmetrical Folds, 511; African Erosion Surfaces, 513.

Reviews.-Fossil Men : A Textbook of Human Palaeontology, 514 ; Man's Journey through Time: A first step in Physical and Cultural Anthropology, 514.

Publications Received.-515.

INDEX.-517. 